\title{
Article
}

\section{Let Bengal be Heard: Dealing with Covid and Cyclone Amphan together}

Majumdar, Boria

Available at http://clok.uclan.ac.uk/33634/

Majumdar, Boria (2020) Let Bengal be Heard: Dealing with Covid and Cyclone Amphan together. South Asian History and Culture, 11 (3). pp. 317-322. ISSN $1947-2498$

It is advisable to refer to the publisher's version if you intend to cite from the work. http://dx.doi.org/10.1080/19472498.2020.1780063

For more information about UCLan's research in this area go to

http://www.uclan.ac.uk/researchgroups/ and search for <name of research Group>.

For information about Research generally at UCLan please go to http://www.uclan.ac.uk/research/

All outputs in CLoK are protected by Intellectual Property Rights law, including Copyright law. Copyright, IPR and Moral Rights for the works on this site are retained by the individual authors and/or other copyright owners. Terms and conditions for use of this material are defined in the policies page. 


\section{Let Bengal be Heard: Dealing with Covid and Cyclone Amphan together.}

\author{
Boria Majumdar ${ }^{1}$ \\ University of Central Lancashire \\ (cristorian@yaho0.com) XXXX and Sunipa DasGupta $\stackrel{2}{-}$ \\ (sunipa@epw.in) is a senior assistant editor at the-Economic and Political Weekly
}

\begin{abstract}
:
Reeling under the double burden of a biological and a natural disaster, West Bengal_-needs civil society mobilisation in terms of both local and global synergy to rebuild the state and its economy. By acknowledging the lack of constitutional clarity regarding "disaster" and hence the inherently conflicting centre-state relationship over disaster management, this paper argues that exclusive dependency on the government will yield no result at this hour. What is needed is a partnership between government and private initiatives and the civil society, especially the Bengal diaspora.
\end{abstract}

Keywords: Cyclone Amphan, pandemic, disaster management, civil society, Bengal diaspora

\section{Introduction}

Super cyclone Amphan, which made landfall in Bengal on 20 May 2020 has broken the backbone of a state, already crippled by the Covid 19 pandemic and subsequent lockdown. With COVID-19 being on a rising curve and a sudden stoppage of all economic activities due to the lockdown for over two months at a stretch, West Bengal was already juggling with three goals that could be potentially mutually exclusive. First, to contain the increasing onslaught of the disease; second, to revitalise a dampened economy; and third, to manage the state's financial resources to mitigate these equally forceful but opposite movements of the contagion and the economy.

The intensity and implication of the devastation of a three-hour cyclone both outweighs and intensifies the devastation caused by the pandemic. In three months, India has reportedly 2.16 lac COVID infected people with a recovery rate of $48 \%$, while the cyclone in merely three

${ }_{1}^{1}$ Email_cristorian@yahoo.com.

${ }^{2}$ Email: sunipa@epw.in.
Formatted: Centered

Formatted: Font: Bold

Formatted: Font: Bold

Formatted: Font: Bold

Formatted: Font: Bold

Formatted: Font: Bold

Formatted: Font: Bold

Formatted: Font: Times New Roman, 12 pt

Formatted: Font: Times New Roman, 12 pt

Formatted: Font: Times New Roman, 12 pt

Formatted: Font: Times New Roman, 12 pt

Formatted: Font: Times New Roman, 12 pt, English (United Kingdom)

Formatted: Font: Times New Roman, 12 pt

Formatted: Font: Times New Roman, 12 pt

Formatted: Font: Not Bold

Formatted: Font: Not Bold

Formatted: Font: Times New Roman, 12 pt, English (United Kingdom) 
hours impacted the lives and livelihoods of 6 crore people in the state of West Bengal alone(Data from the Ministry of Health and Family Welfare 04 June 2020). Further, the cyclone situation possiblyean triggered a vicious cycle of contamination. Coastal districts like North 24 Parganas and East Midnapore, which were under high alert, are also among the covid-19 hotspots in the state.

According to official reports, over 3 lakh people in the high alert coastal districts were evacuated to around 100 evacuation centres, making an estimated average rate of 3,000 people per centre. In comparison, during cyclone Bulbul in 2019, an estimated 1.8 lakh people were evacuated to these centres (The New Indian Express 03 June 2020). This implies that Amphan evacuation meant the cramming of a maximum of people in the shelters to protect their lives from a natural calamity, in turn increasing their risk exposure to a health calamity since social distancing could not be practised. That was's the irony of the whole situation- Bengal was dealing with a volcano and an avalanche at the same time.

Therefore, the three potentially mutually exclusive issues that we mentioned above- are now almost the three "burn down" rates ${ }^{1}$ that the state has to grapple with. For instance, according to official estimates the state has lost Rs.12,000 crore in the last two months in the wake of COVID-19 (The New Indian Express 03 June 2020), while the estimated loss due to the cyclone is nearly Rs. 1 lakh crore (India Today 22 May 2020). Again, the state government had announced a Rs.1.52 lakh crore stimulus package for restarting the lockdown affected economy, especially its rural and small business (MSME) sectors. Intuitively, this package will now fall further short confronted by the additional losses caused by the cyclone, not to mention the challenges for rural infrastructure development -identified as a key driver of the state's economy in the post-COVID situation by the government due to the destruction of the erstwhile existing infrastructure. For example, according to the official statements $99 \%$ a huge percentage of the South 24 Pargana district has been wiped out (India Today 22 May 2020).

The most pressing question at this point is how the state can rebound from this situation. In this paper we try to explore this question from the perspectives_-of three aspects of disaster mitigation, namely_-governance, cooperative federalism and resilience, only to begin with a first-hand account of the cyclone's onslaught, especially on the state's capital, Kolkata.

\section{Experiencing the cyclone}

It was about $7 \mathrm{pm}$ on 20 May and Amphan had a complete grip on us. The wind speed was up and the sound was growing louder each minute. A 
shrill, cruel, hissing noise, which was starting to get alarming. The door to Boria's terrace, made of solid $19^{\text {th }}$ century wood, was starting to make creaking sounds raising doubts if it could survive the ordeal. If the door failed the family, there was no further protection. That's when Aisha, Boria's daughter who is 6, came up and asked, "Babba will the cyclone come inside and blow us away?" She hardly understood what Amphan was and for her Babba is always the pillar of strength who can solve all problems. Only this time he was helpless. While he said to her nothing will ever happen to the family, the words were sounding hollow in his own ear. He was scared and there was no way he could hide it. His The house, a typical $19^{\text {th }}$ century north Kolkata buildingresidence, is surrounded by a number of trees and the first thought was, if one of them fell on the terrace; it willwould be a real nightmare to deal with. In fact, two of the trees on either side of the house did break but by some miracle hand of fate both fell on the road with the surrounding dwellings left untouched.

Had one of these fallen 25 feet on either side, the building could have witnessed-serious damage.

Windowpanes lay all over and water was rushing in from the broken windows. It was as if someone was trying to water a garden with a hose pipe. He tried his best to block the flow but after a couple of minutes realised that Amphan was far too powerful. Best was to give up and just wait for the cyclone to have pity on us and move on.

When we think back, we have to say theThe period between $7 \mathrm{pm}$ and $8 \mathrm{pm}$ was the worst. We had endured the trauma for more than three hours and patience was starting to run out. Hope was giving way to fear, and stories of power outage and flooding was-were coming in from everywhere. Every tweet that said it was going past Bengal was a ray of hope. True or not it did not matter. We just wanted to hear something positive and start to feel we were nearing the end of it. Finally, around 10:15pm the wind started to subside. It was hope. The cyclone had passed us in Kolkata, but the state was still not out of danger.

While the cyclone had gone past us, the reality of destruction was to unfold the next morning. Neither of us wanted to face the reality the next morning and look around. And when we did our worst nightmare was a living reality. Boria's house in north Kolkata was surrounded by fallen trees and it was as if the family was living in on an island engulfed-surrounded by water-on all sides. Shocked eitizens-neighbours had started to step out with looks of horror writ large and most started taking photos and making videos of the scene of destruction. This was not something they would ever again see. Or so we hope. Tram wires had snapped, and 
the bolts were hitting against the fallen pole of the lamppost making a strange sound. It was a reminder of the early morning tram .

The first thing everyone did was checkEverybody had checked en-their phones. There was signal but it seenConnectivity was tmrned-erratic at best. The water line in some houses was still intact and in some areas there was power. We were the lucky few who hadA lucky few had had power all through. While battling covid and enforcing the lockdown and social distancing, we need to deal with the aftereffects of Amphan. It will testWhat was to come would test the resolve of the best of political leaders and also of civil society. No mobile connections, no power and no water aren't things we deal with every day. While Amphan is finally beyond us, the scarring remains.

And will remain forever.

Against Covid we have reason to believe we can save ourselves with proper behavioural hygiene, social distancing and early detection. Against Amphan we were all dead ducks sitting and waiting to be consumed by the fury of the wind.

\section{Disaster management and governance}

In the case of a hurricane it takes nine to ten days for power to come back in parts of the world.-During cyclone Aila in 2009 it took eight days for things to return to normal in Bengal. Amphan has caused destruction; which is 10 times higher and yet we had some semblance of functionality withiin a week.

Kolkata, a city we surveyed extensively, was functional in a-under a week. A tour of the city on 21 May, athe day after the cyclone, was the a most painful thing to undertake. Every main road or by-lane had trees blocking the way and key thoroughfares like Park Street resembled a-jungles. From one end of Park Street it was impossible to see the other side with giant trees obstructing the view. Power and cable television lines lay all over the roads and lamp posts were either half bent or broken. It was as if the city had been bombed. Thousands of households were without electricity and water, and citizens had lost out on-the very basics of life that, which we take for granted.

At some places there were protests demanding restoration of services, gatherings which violated prescribed social distancing norms for COVID. On the third and fourth days from the cyclone, the situation got progressively better with the protests 
restricted to certain pockets of the city. By 24 May 2020, close to $9 \underline{4} \%$ of the city had power and water back and most roads had been made navigable with trees moved to one side and awaiting clearance. It was by 30 May, 10 days after the cyclone that the city had power and phone connections restored, and a sense of normalcy.

Deployment of the army in clearing out trees, with teams from the National Disaster Relief Force and State Disaster Relief Force working round the clock helped in speeding up relief work. Protests abated with time, but health experts warned that violation of social distancing norms could haunt the city in the weeks to come. On the other hand, however, politics over the cyclone was also reaching a furious pitch with the state and central governments locked in a war of words blaming each other for the state-level of preparedness.

While the need for effective coordination in disaster relief system-is ubiquitously accepted, yet global experiences from various disaster affected countries show that intrusion of political considerations in relief efforts, whether at the local or international level, comes in the way of the egalitarian principle in relief (Sheer 1976, Max 1979). In the Indian scenario, various studies analysing the politics of calamity management have found that the character of relationship and mutual perception between the politicians and the bureaucracy, the centre and the state etc. can significantly change the demands and goals of the task system (Mathur and Bhattacharya 1975, Cohen and Raghavulu 1977).

Ironically, while the biological disaster of COVID-19 is handled by the imposition of the disaster management act, 2005, which has the legislative intent to "provide for the effective management of disaster", it is surprising that the management of a natural calamity like the Amphan is not under any such legal or constitutional provisions, despite inflicting human miseries of an equal, if not higher, intensity as the pandemic. Though the Constitution of India is silent on the subject of "disaster", yet the legal basis of the disaster management act formed by Entry 23 of the concurrent list of the Constitution, is for "social security and social insurance". Given that, why does Amphan remain only Bengal's crisis and not a national disaster is the question we want to dwell upon?

\section{Cooperative federalism}

While in the Indian federal polity disaster mitigation appears to be the joint responsibility of the centre and the state governments, the constitutional silence or lack of clarity on critical issues like the definition of disaster, the modalities of expenditure sharing between the centre 
and the state governments for relief and rehabilitation can dilute the potential of cooperative federalism on this issue. Bose (1994) pointed out that there are distributional aspects involved in calamity management and "political elites who are in constant competition are prone not to leave any stone untouched when it comes to making political capital".

Again, Raghavulu and Bose (1992) noted that: "Conflicts were most prominent over policies pursued by the Centre and states concerning natural disasters such as the set procedures, and the quantum of assistance, role of various agencies in disaster relief operations, accounting procedures, damage assessment, etc. In this context, it is not uncommon for Central and state Governments, belonging to different political parties, to indulge in mutual accusation"

Given this backdrop, the persistent cry of the states that they have been getting a raw dealdeprived regarding of the statutory and discretionary financial allocations to them by the central government remains a real concern. Though the recommendations of the successive finance commissions, especially since the sixth one, seem to recognise the nature of the problem, yet their cumulative impact has not been adequate to meet the challenge of financial burden to the states during disaster mitigation.

While Bengal's resources are stretched at the moment for meeting the combined attack of the pandemic and the natural calamity, it has to be borne in mind that this short fall has not been triggered by the disasters. According to the state government's 2020-21 budget declaration, the state was already denied more than Rs.50,000 crores in dues from the central government, which is nearly 4.5 times higher than the amount denied in 2019-20 and comprises of Rs. 1,300 crore goods and services tax (GST) compensation due to the state from the central government (Business Standard February 10, 2020). But that doesn't does not stop us from sharing the ground reality and trying to come together.

\section{Resilience and The Need for A Global Response}

It was one of the many villages in the North 24 Parganas that we visited in the aftermath of Amphan. Only this one had no roads left. The car could go up to a certain point and then it was all water and carnage. As we got off the vehicle and started to look around, we could see a woman swimming across a stretch of water with a young child holding on to her. It was an astonishing sight. How she managed to swim with the child next to her is a miracle. And when she reached the end of the stretch of water, she disappeared behind a tree, changed, and started to walk past us. When we asked her what she was trying to do she pointed us to her house on the other side of the stretch of water. There was no road left that could connect her 
to shops from where she could buy food and swimming was her only option. She would swim across, buy food and then swim back again. Once she told us what she was doing twice daily, we were left with no words to console her. She was for us the real story of what Cyclone Amphan had done to people in Bengal.

In the past couple of months, a word that has been abuzz in public discussions and discourses is "resilience". According to Hollings (1973) resilience is described as the capacity of ecosystems to bounce back to their original state after being subjected to perturbations. Given this double burden of biological and natural calamities, resilience has assumed novel implications for combating the hazards in the state of West Bengal.

In the 24 parganas alone, where more than 10 lac dwellings have collapsed, the aforesaid story of resilience is one of "adaptive practises". At the other end of the spectrum are reactions like "We don't have water and we don't have electricity. Wearing a mask can wait", by an angry villager to one of the law enforcement officials in a village next to Digha. This too, is another kind of resilience through "pressure tactics". While there might be concerns about whether our policy imagination perceives resilience as part of a feasible policy structure, especially when its attainment and challenges vary across the social classes, there is no denying that some sort of resilience is needed for the state to bounce back.

In every briefing since January 2020 on the evolving Covid 19 crisis, the World Health Organisation Chief Dr. Tedros mentions the need for global solidarity to deal with a catastrophe of this nature. National unity and global solidarity remain the buzzwords according to him to solve the problem. For cyclone Amphan ravaged Bengal, the same yardstick should apply for that too has been a crisis of unprecedented scale. Kolkata, it must be emphasised, has never seen a catastrophe of this scale and magnitude in the last few decades. Moreover, this crisis, as discussed in the introductory section of this paper, has put the state on "burn down" curve.

To deal with a tragedy like this we need to muster every resource and coping strategy we possibly can, to try and rebuild the state and its economy. An example to substantiate the point. The Bengali diaspora, which is well spread out across the world will inevitably have a sense of nostalgia for the College Street Book market, a heritage site of the city. The market today stands destroyed. Books worth a crore have been damaged and sellers are left with wet or damaged stock, which threatens to throw them out of business. If this news reaches the men and women of the city who are spread across the world there is every reason to believe 
there will be a call to action. A micro plan can then be made to resurrect College Street. It can be a civil society driven action plan led by academics and intellectuals working in close proximity with the book sellers and civic officials.

To expect that the government will mount all relief efforts is a mistake. The government canno't. It doesn't have the means and never will. The scale of destruction is such that we need synergy. We need a partnership between government and private initiatives and civil society. We need the diaspora to step in and play an active role. And that i-s where we have fallen short. The coverage in the world media has been negligible. Major national platforms have hardly reported the tragedy. As a result, people are non't aware of the scale and magnitude of the devastation. All we need now is a voice and the world media is the option to make us heard.

\section{Lending A Voice to Bengal's Crisis}

In sum, we need awareness of what has happened in Bengal. We need people to write, talk, tweet, comment, post, showcase and argue. We need dialogue across the world to highlight the plight of millions. We need to showcase how the state is working on war footing to get things back on track. We need the world to see the efforts being made and subsequently contribute to such efforts for only then can true global solidarity play out in reality.

We need the world to see this and help us going forward. If that happens, the functionality can be taken two steps ahead and normalcy can return much faster than anticipated. We need to empower the men and women who are suffering and that can only happen if the world understands and highlights the goings on in Kolkata and Bengal. Bengal is not a remote island that can-could be left to fend for itself. It is as much part of the global dialogue as New York or Mumbai is. If there could be global synergy for the Australian Bushfires, which raved the country in January 2020, there is no reason why the world cannot't come together for Bengal.

The road ahead is a long and tough one. At the same time there is no reason to lose hope. The worst is over, and it can only get better. The world coming together to help can help-speed up the process.

\section{References:}


Bose, BPC (1994): “The Politics of Disaster", The Indian Journal of Political Science, Vol 55, No 2, pp. 119-134.

Business Standard: "West Bengal dues from Centre more than Rs 50,000 crore: Amit Mitra", 10 February 2020

Cohen, S.P. and C.V. Raghavulu (1979), The Andhra Cyclone, 1977: Individual and Institutional Responses to Mass Death, Vikas, New Delhi, 1979.

India Today: "Cyclone Amphan: West Bengal govt puts losses at Rs 1 lakh crore”, 22 May 2020.

Mac Marshall (1979), "Natural and Unnatural Disasters in the Mortlock Islands of Micronesia", Human Organization, Vol. 38, No. 3, pp. 265- 272

Mathur, K. and Mohit Bhattacharya (1975): Administrative Response to Emergency: A Study of Scarcity Relief Administration in Maharashtra, Concept, New Delhi, 1975

Raghavulu CV and BPC Bose (1992): "Centre-State Relations in Disaster Mitigation and Preparedness", The Indian Journal of Political Science, Vol 53, No 3, pp. 314-331.

Sheer, David (1976), "International Long-term Planning for the Sahel", International Development Review, Vol. 18, No. 4, pp. 15-20.

The New India Express: “Cyclone 'Amphan': West Bengal Government Mounts One of Its Biggest Evacuation Exercises", 03 June 2020.

\section{Endnotes}

1 Burn rate or burn down rate is a term from project management used to capture the work remaining in a project or iteration against the iteration timeline. Here we are using the concept to reflect the urgency of a situation which is almost equivalent to fuses burning and time to retrieve is limited, more so due to a lack of clarity about the estimated time for the entire process of burning to complete. 